\title{
Unusual drift behaviour of multi-year sea ice in the Beaufort Sea during summer 2018
}

\author{
Noriaki Kimura, ${ }^{1}$ Kazutaka Tateyama, ${ }^{2}$ Kazutoshi Sato, ${ }^{2}$ Richard A. Krishfield ${ }^{3}$ \& Hajime Yamaguchi ${ }^{4}$ \\ ${ }^{1}$ Atmosphere and Ocean Research Institute, The University of Tokyo, Kashiwa, Japan; \\ ${ }^{2}$ Kitami Institute of Technology, Kitami, Japan; \\ ${ }^{3}$ Woods Hole Oceanographic Institution, Woods Hole, MA, USA; \\ ${ }^{4}$ Graduate School of Frontier Sciences, The University of Tokyo, Kashiwa, Japan
}

\begin{abstract}
In summer 2018, thick sea ice blocked the mouth of the Amundsen Gulf (AG), Canada, obstructing shipping through the North-west Passage. This study analysed multi-year ice motion to investigate the source of this thick ice and the reasons for its unusual movement. For this purpose, a daily multi-year ice distribution product was generated by ice tracking using gridded daily seaice velocities (2003-2018) derived from the AMSR-E and AMSR-2 data. From autumn 2017 to summer 2018, the area of multi-year ice extended westward to the Beaufort Sea and then migrated towards the AG mouth. The primary cause of the unusual ice cover was anomalous AG-ward wind in September 2018. It is known that multi-year ice has become increasingly moveable over the past decades, as indicated by the increasing wind factor (i.e., ratio of icedrift speed and wind speed), but the unusual ice motion in the summer of 2018 cannot be explainable by the wind factor alone. Accurately, predicting monthly wind and monitoring old thick ice will reduce the risk posed by thick Arctic sea ice to shipping.
\end{abstract}

\begin{abstract}
Correspondence
Noriaki Kimura, Atmosphere and Ocean Research Institute, The University of Tokyo, 5-1-5 Kashiwanoha, Kashiwa 277-8568, Japan. E-mail: kimura_n@aori.u-tokyo.ac.jp

Keywords

Sea-ice motion; satellite remote sensing; shipping; North-west Passage

Abbreviations

AG: Amundsen Gulf

AMSR-2: Advanced Microwave Scanning Radiometer, onboard the Global Change Observation Mission for Water-1 satellite AMSR-E: Advanced Microwave Scanning Radiometer for Earth Observing System, onboard the Aqua satellite AO: Arctic Oscillation ASSIST: Arctic Shipborne Sea Ice Standardization Tool (observation protoco of ASPeCT)

ASPeCT: Antarctic Sea Ice Processes and Climate (expert group on Antarctic sea-ice zone research within the Physical Sciences programme of the Scientific Committee on Antarctic Research)

ERA-Interim: global atmospheric reanalysis data set produced by the European Centre for Medium-Range Weather Forecasts JOIS: Joint Ocean Ice Study (international oceanographic monitoring programme)
\end{abstract}

\section{Introduction}

The areal extent of summertime ice in the Arctic Ocean has exhibited a downward trend since the last century (e.g., Stroeve et al. 2007; Cavalieri \& Parkinson 2008, Cavalieri \& Parkinson 2012). Moreover, the sea-ice volume has also reduced radically (e.g., Kwok \& Cunningham 2015). Monitoring the thickness of sea ice as well as its area is important to improve our understanding of the present state of the Arctic climate. Nowadays, seaice thickness can be monitored by several means using data from satellite microwave sensors (Krishfield et al. 2014) or radar/laser altimeters (e.g., Ricker et al. 2014).
However, there are difficulties in the derivation of ice thickness from remote sensing data, especially in summer owing to unstable conditions of the ice surface, for example, melt ponds.

Multi-year ice, which is defined as ice that has survived the summer and includes second-year (and older) ice, is an important factor controlling sea-ice distribution and thickness (Tschudi et al. 2016). Monitoring areas of multi-year ice is important because its distribution and movement can alter the distribution of thick ice (Hutchings \& Rigor 2012; Haas et al. 2017; Barber et al. 2018; Mahoney et al. 2019). Many previous studies that have focused on multi-year ice distribution have estimated 
the age of the sea ice in the Arctic (e.g., Maslanik et al. 2007; Maslanik et al. 2011; Korosov et al. 2018) and reported a reduction of thick multi-year ice (e.g., Comiso 2012). Conversely, some other studies have shown that the reduction of the area of multi-year ice has not been significant during the past 10-year period (Kwok 2018; Tilling et al. 2018). Galley et al. (2016) reported that the multi-year ice fraction in the Beaufort Sea has decreased in the past several decades. To understand the processes controlling the spatiotemporal changes of Arctic sea ice, special attention must be paid to the interannual variability of the multi-year ice cover.

Sea-ice reduction in the Arctic Ocean offers new opportunities for commercial shipping routes across the Arctic. However, rapid unexpected movement of thick ice can obstruct shipping routes for short periods. This study focusses on one such event, in which thick ice blocked the mouth of the AG in September 2018 (Fig. 1). This blockage temporarily prevented the navigation of ships in and out of the western entrance to the North-west Passage, resulting in cancellation of the annual supply barge to three Arctic communities (Weber 2018). Understanding the circumstances of the 2018 blockage will help improve sea-ice forecasting in the Arctic and reduce the impact of sea route blockages. The objective of this study was to reveal both the source of the thick ice in the AG blockage of 2018 and the reasons for the unusual drift behaviour of the multi-year sea ice.

\section{Data and methods}

Ice concentration and multi-year ice distribution derived from AMSR-E and AMSR-2 data were prepared for use in this study. Daily ice concentration data were calculated using a bootstrap algorithm (Comiso 2009). These data are provided on a polar-stereographic grid with 10-km spatial resolution by the Japan Aerospace Exploration Agency and distributed via the Arctic Data Archive System.

There are several ways to monitor the distribution of multi-year ice, for example, taking snapshot observations of its surface properties (e.g., Aaboe et al. 2017) and performing long-term tracking (e.g., Korosov et al. 2018). This study estimated the daily distribution of multi-year ice using a Lagrangian tracking method based on daily ice velocity. Ice velocity can be derived from the gridded brightness temperatures acquired via the $36 \mathrm{GHz}$ (December-April) and $18 \mathrm{GHz}$ (MayNovember) channels of the AMSR-E and AMSR-2. The

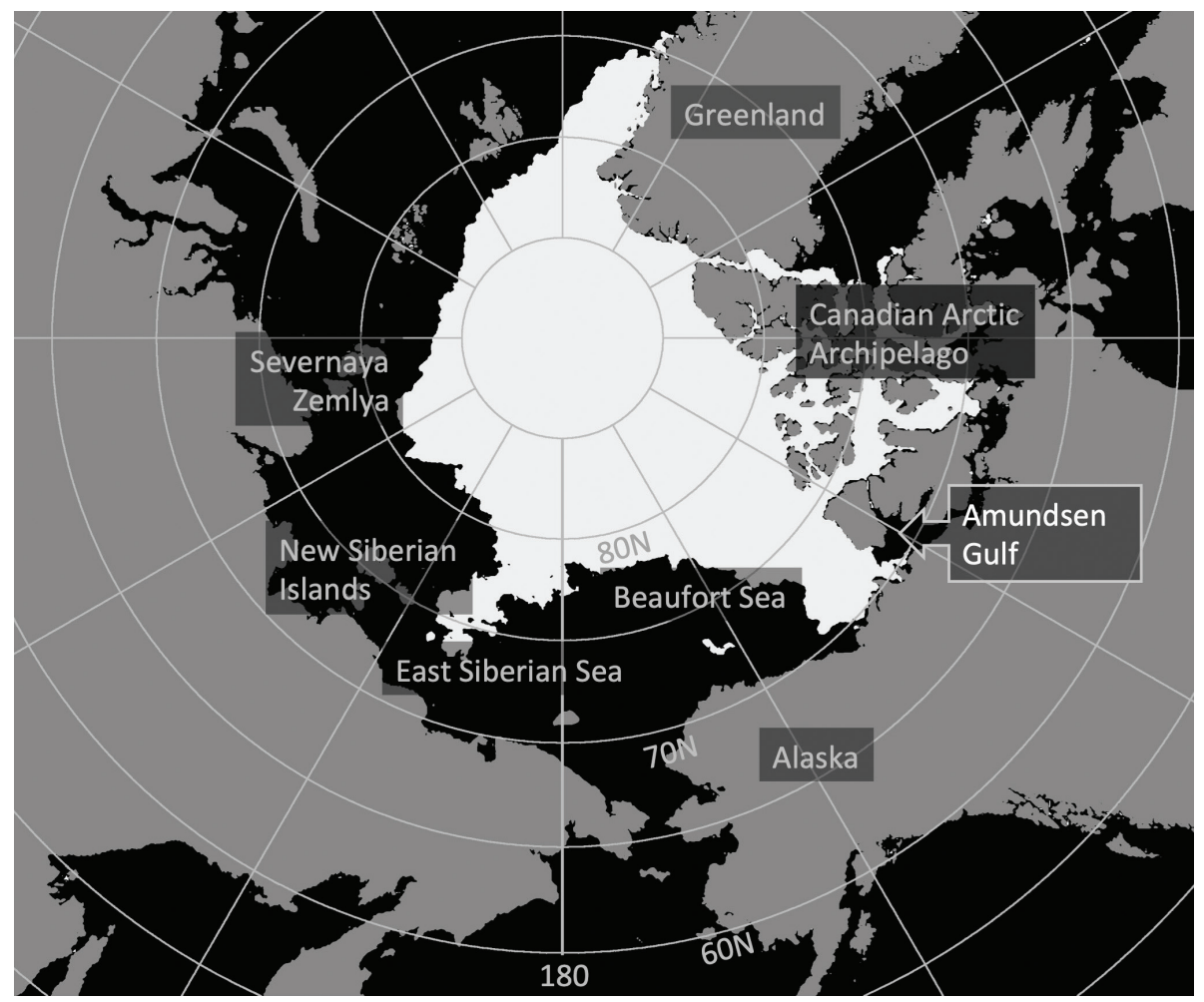

Fig. 1 Map of the Arctic region with the sea-ice area, shown in white, on 30 September 2018 . Sea-ice area is defined as grids cells with ice concentration >15\%. 
method of derivation is based on pattern matching, that is, the maximum cross-correlation technique (Kimura et al. 2013). A data set of daily ice velocity without missing data over the sea-ice area on a $60 \times 60 \mathrm{~km}^{2}$ grid was prepared for 2003-2018, except for September 2011 to July 2012, when there was an observational gap between AMSR-E and AMSR-2. Using this ice velocity data set, the distribution of multi-year ice was estimated by tracking the movement of virtual Lagrangian ice particles, as by Kimura et al. (2013). First, particles were arranged at $10-\mathrm{km}$ intervals over the ice area on the day with the minimum ice cover for each year. The initial distribution of the particles changed annually depending on the interannual difference in the minimum ice area. Then, the displacements of the particles released on 15 September were calculated from the ice velocity in time steps of one day. The ice velocity at the position of each particle was interpolated from grids within $120 \mathrm{~km}$, weighted by a Gaussian function of distance between the particle and the data grid positions. This procedure was used to estimate the temporal change of multi-year ice distribution from 15 September to the end of October the following year. Additionally, each particle includes information on ice concentration. The initial concentration of each particle sets the observed ice concentration on the initial day of minimum ice cover. When the observed ice concentration at the position of a particle was smaller than that of the particle, the concentration was reset to the observed concentration. If the ice concentration was $<15 \%$, the particle was deleted. Based on the multi-year ice concentration of each particle, the concentration of multi-year ice on a $60 \times 60 \mathrm{~km}^{2}$ grid was calculated as the sum of the multi-year ice concentration for particles within a circle of $240-\mathrm{km}$ radius divided by the area of the circle. The multi-year ice data covered the period from 15 September 2013 to 31 October 2018 , except for the data-gap period in 2011-12.

In addition to the information on sea ice derived from satellite remote sensing, ship-based observations of ice thickness were acquired between 6 September and 2 October 2018 during the JOIS 2018 cruises with the icebreaker CCGS Louis S. St-Laurent. Ice thickness was estimated hourly through visual inspection, which is an approach based on ASSIST observation protocol of the ASPeCT protocol (Worby \& Alison 1999).

To estimate the atmospheric conditions, sea-level pressure was obtained on a $0.75^{\circ} \times 0.75^{\circ}$ grid from the ERA-Interim reanalysis data set (Dee et al. 2011), provided by the European Centre for Medium-Range Weather Forecasts. Additionally, the daily geostrophic wind velocity was calculated from the sea level pressure using the following equation:

$$
\begin{aligned}
& U_{g}=-\frac{1}{\rho f} \frac{\partial P}{\partial y} \\
& V_{g}=\frac{1}{\rho f} \frac{\partial P}{\partial x},
\end{aligned}
$$

where $f$ is the Coriolis parameter, $\rho$ is density and $P$ is the pressure.

The wind factor (ratio of ice drifting speed to wind speed) was calculated using a least squares technique based on the linear relationship (Thorndike $\&$ Colony 1982) between daily sea-ice velocity and geostrophic wind velocity, using the calculation method of Kimura $\delta$ Wakatsuchi (2000).

\section{Sea-ice conditions in 2018}

The temporal and spatial changes of sea-ice cover and multi-year ice distribution from autumn 2017 to summer 2018 are shown in Fig. 2. The sea-ice area reached its maximum extent in March and then retreated rapidly during May-September. The multi-year ice distribution in the central Arctic shrank, leaving narrow branches, extended to the New Siberian Island and Severnaya Zemlya. Conversely, the area of multi-year ice expanded towards the Atlantic side along the north and west coasts of Greenland via the Transpolar Drift Stream and the East Greenland Current and towards the North American side (hereinafter the "Beaufort branch"), moving across the Beaufort Sea to the East Siberian Sea under the influence of the prevailing clockwise Beaufort Gyre. Although the Beaufort branch disappeared in summer in association with ice retreat, the blockage at the mouth of the AG occurred in September following the migration of the trunk of the Beaufort branch towards the AG. Multiyear ice parcels reached the Canadian coast by the end of September.

The multi-year ice distribution estimated by the particle tracking method agrees well with the observed area of thick ice (Fig. 3). This indicates that most of the ice blocking the mouth of the AG was multi-year ice with thickness $>1 \mathrm{~m}$.

To clarify the unusual ice behaviour in 2018 , the interannual difference of the sea-ice cover and multi-year ice distribution on 30 September in each of the studied years is presented in Fig. 4. Additionally, Fig. 5 shows the interannual variation of total ice concentration and of multiyear ice concentration on 30 September in each of the studied within circles A and B depicted in Fig. 4. Area A (a few hundred kilometres from the mouth of the AG) was covered by sea ice in September almost once every four years because of the overhang of the Beaufort branch of multi-year ice. In those years, half the sea-ice cover in 

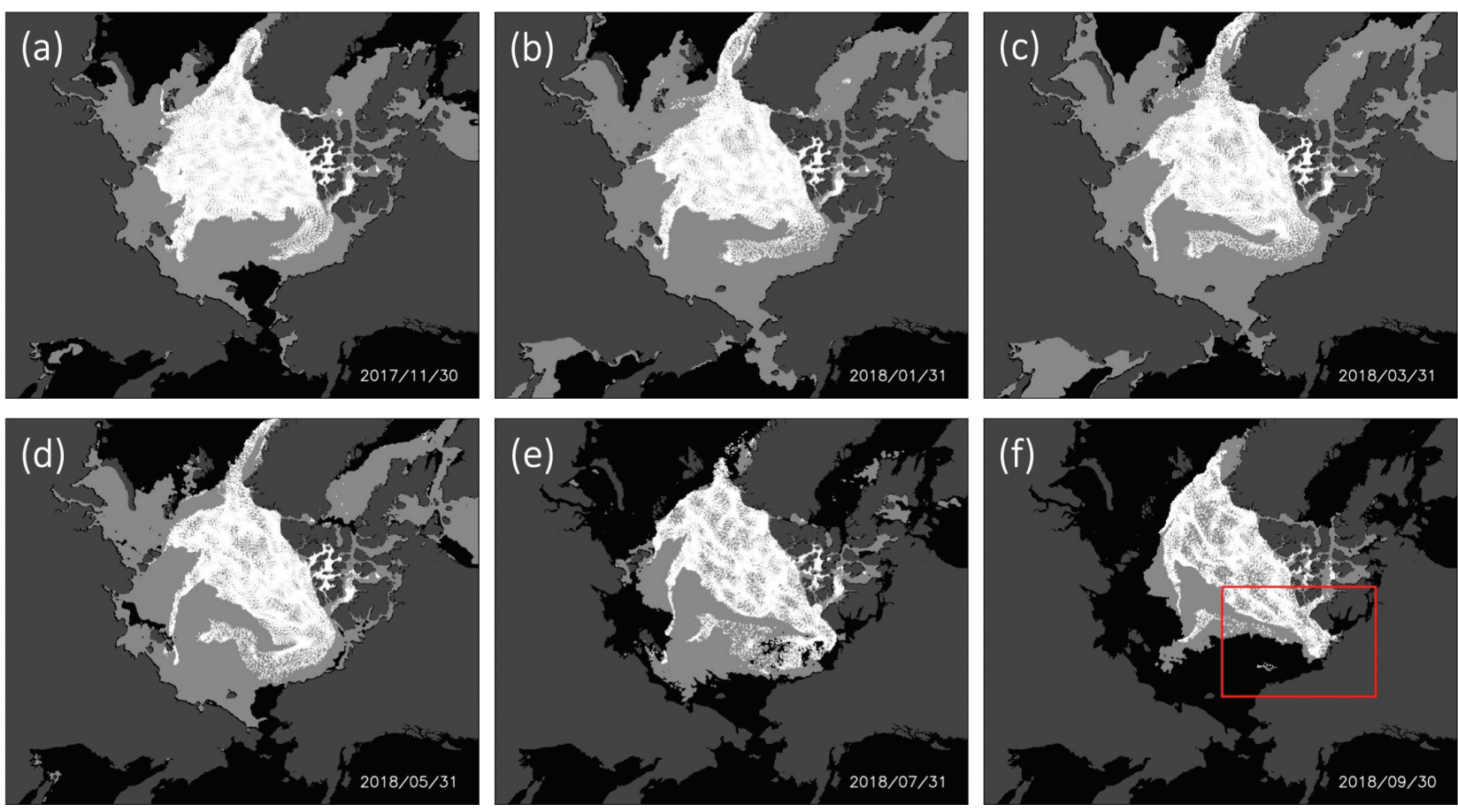

Fig. 2 Sea-ice area (grids cells with ice concentration >15\%, shown in light grey) and multi-year ice distribution (white dots) derived in this study: (a) 30 November 2017, (b) 31 January 2018, (c) 31 March 2018, (d) 31 May 2018, (e) 31 July 2018 and (f) 30 September 2018 derived from AMSR-2 data (for details within red rectangle, see Fig. 3).

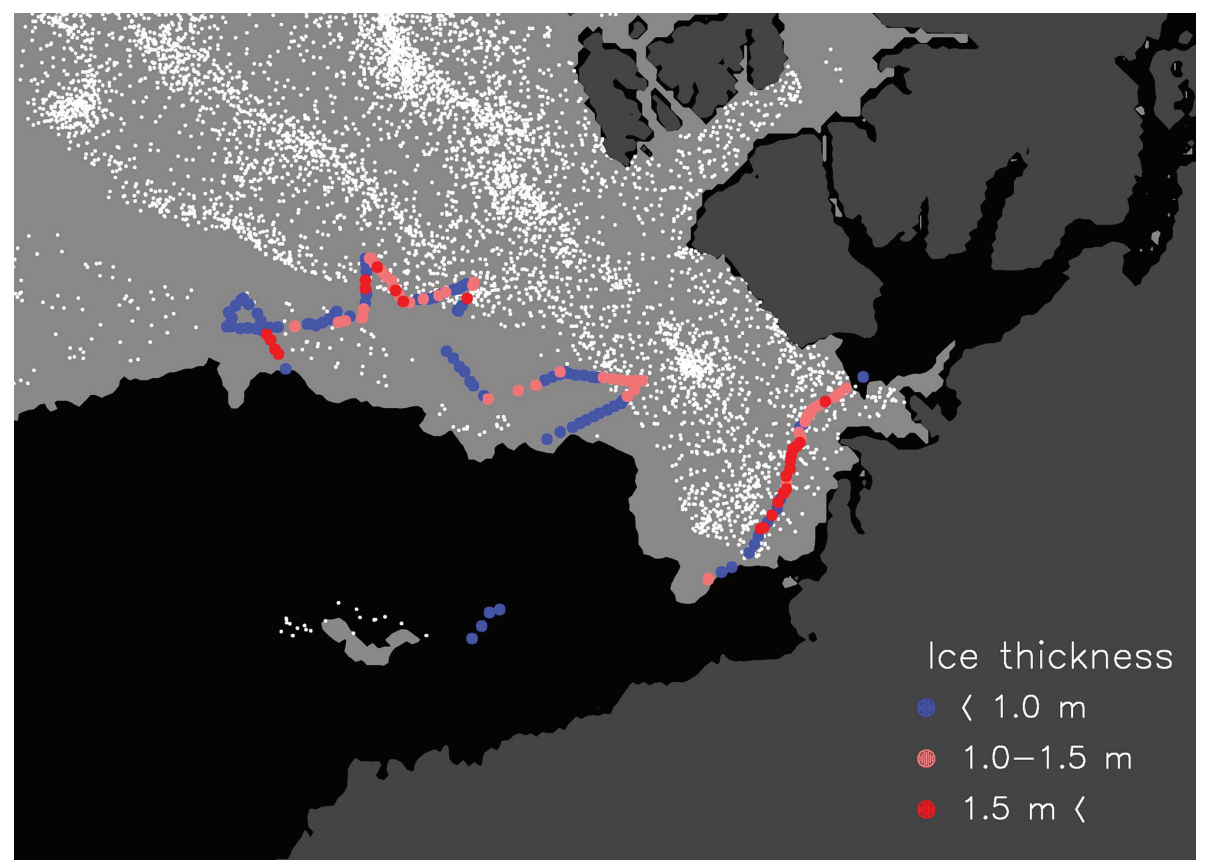

Fig. 3 Close-up image (rectangle in Fig. 2f) of sea-ice cover and multi-year ice distribution for 30 September 2018. Coloured dots show ice thickness along the ship track, as estimated by visual observations. 

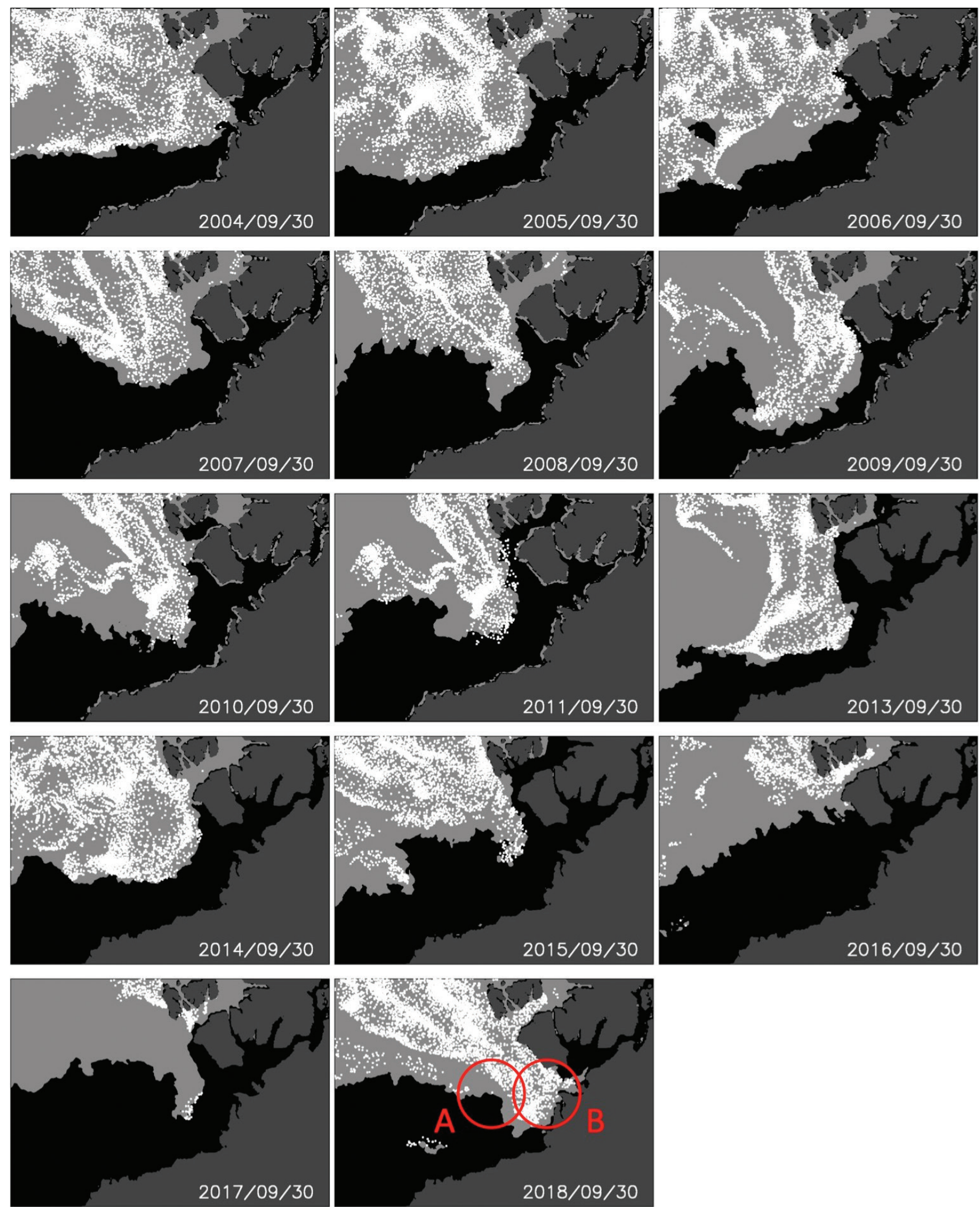

Fig. 4 Interannual differences within the area of interest (rectangle in Fig. 2f) of sea-ice cover and multi-year ice distribution for 30 September 2004-2011 and 2013-18. (Details of ice concentration within circles A and B are shown in Fig. 5.) 

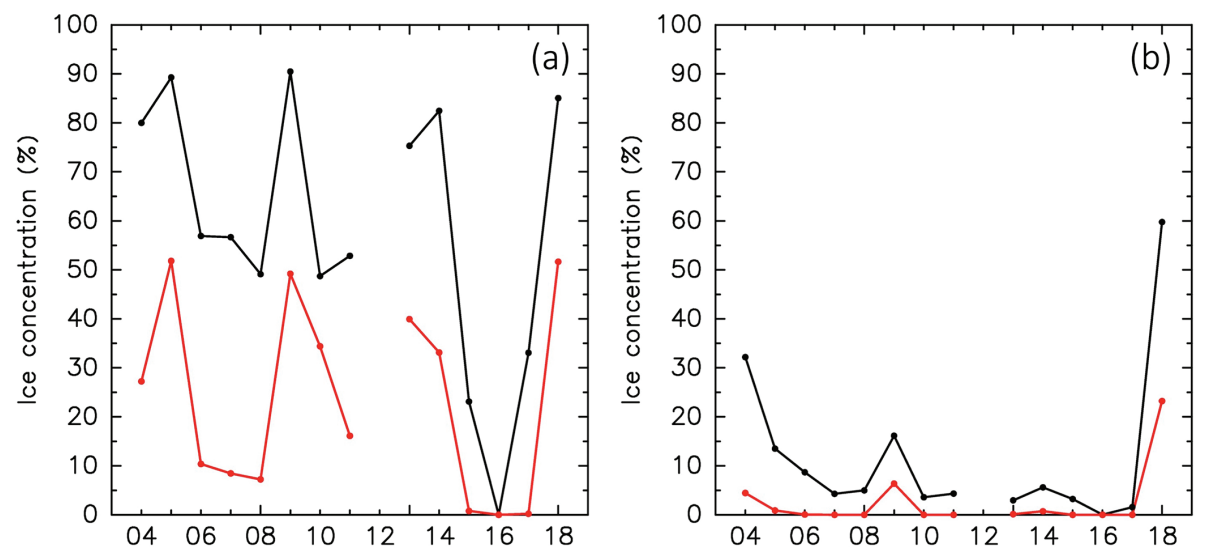

Fig. 5 Interannual variation of total ice concentration (black lines) and multi-year ice concentration (red lines) on 30 September within circles (a) A and (b) B shown in Fig. 4.

area A consisted of multi-year ice. However, it is evident that sea ice rarely covered area B, nearer to the AG, that is, the blockage event that occurred in September 2018 was the only case of ice cover in this area since 2003.

\section{Background of thick ice behaviour in 2018}

The blockage of the mouth of the AG was caused by southward movement of multi-year ice north of the Canadian Arctic Archipelago. The unusual pattern of the sea-ice distribution in summer 2018 was characterized by this southward movement of the Beaufort branch. To help visualize the causes of this behaviour, Fig. 6 presents the difference of ice concentration between the first and last days of each month, and the anomalies of sea-ice motion and sea-level pressure in June, July, August and September 2018, on the basis of the 2003-2018 climatology. During July-August in 2018, most of the marginal ice areas were characterized by negative anomalies in ice concentration, representing the relatively low Arctic-wide sea-ice coverage in these months relative to that in the 2003-2018 period. However, near the mouth of the AG, ice concentration was characterized by a slight positive anomaly. This increase was maintained by the AG-ward (eastward or southward) motion of the ice associated with the AG-ward wind anomaly. A strong low-pressure anomaly over the Arctic Ocean caused the strong AG-ward motion of ice in July. Although the centre of the low-pressure anomaly moved to the Canadian Arctic Archipelago, the AG-ward wind anomaly continued to push multi-year ice towards the AG in August. The largest anomaly of AG-ward ice motion occurred in September, associated with the combination of a low-pressure anomaly over the Canadian Arctic Archipelago and a high-pressure anomaly over Alaska. In addition, the direction of the ice vector anomaly shifted from eastward (along the continental coast) in July-August to south-eastward (towards the continent) in September. Thick multi-year ice reached the coast of the continent in September following this shift in wind direction. The ice concentration near the mouth of the AG increased over hundreds of kilometres during September. This increase can be explained by the anomalous ice motion in this area. The anomaly reached up to $10-15 \mathrm{~cm} / \mathrm{s}$, which is equal to the anomaly in the ice advection distance over 250-400 $\mathrm{km}$ during one month (30 days). Figure 7 presents the interannual change of AG-ward wind at the centre of area B in August and September. In both months, the AG-ward wind was dominant. In particular, the AG-ward wind in September 2018 was exceptionally strong compared with the other 13 years. This unusual onshore wind led to the AG-ward ice motion and the AG blockage in 2018. Notable increase in ice in September was also seen in the Greenland Sea, which can be explained by anomalous wind-driven ice drift. It is evident that the AG-ward wind is not related to the AO index (Fig. 7). The wind direction around the mouth of the AG is controlled by the local atmospheric circulation pattern rather than the Arctic-scale pattern reflected by the AO.

A notable anomaly of ice motion can be caused by a change in the mobility of sea ice in addition to a strong wind anomaly. The wind factor in 2018 was not extraordinary in comparison with the other recent years in the study period (2003-2017; Fig. 8). This means that the unusual motion of multi-year ice in 2018 was caused by the unusual wind field rather than by unusual mobility of the ice. However, with regard to the long-term trends, 

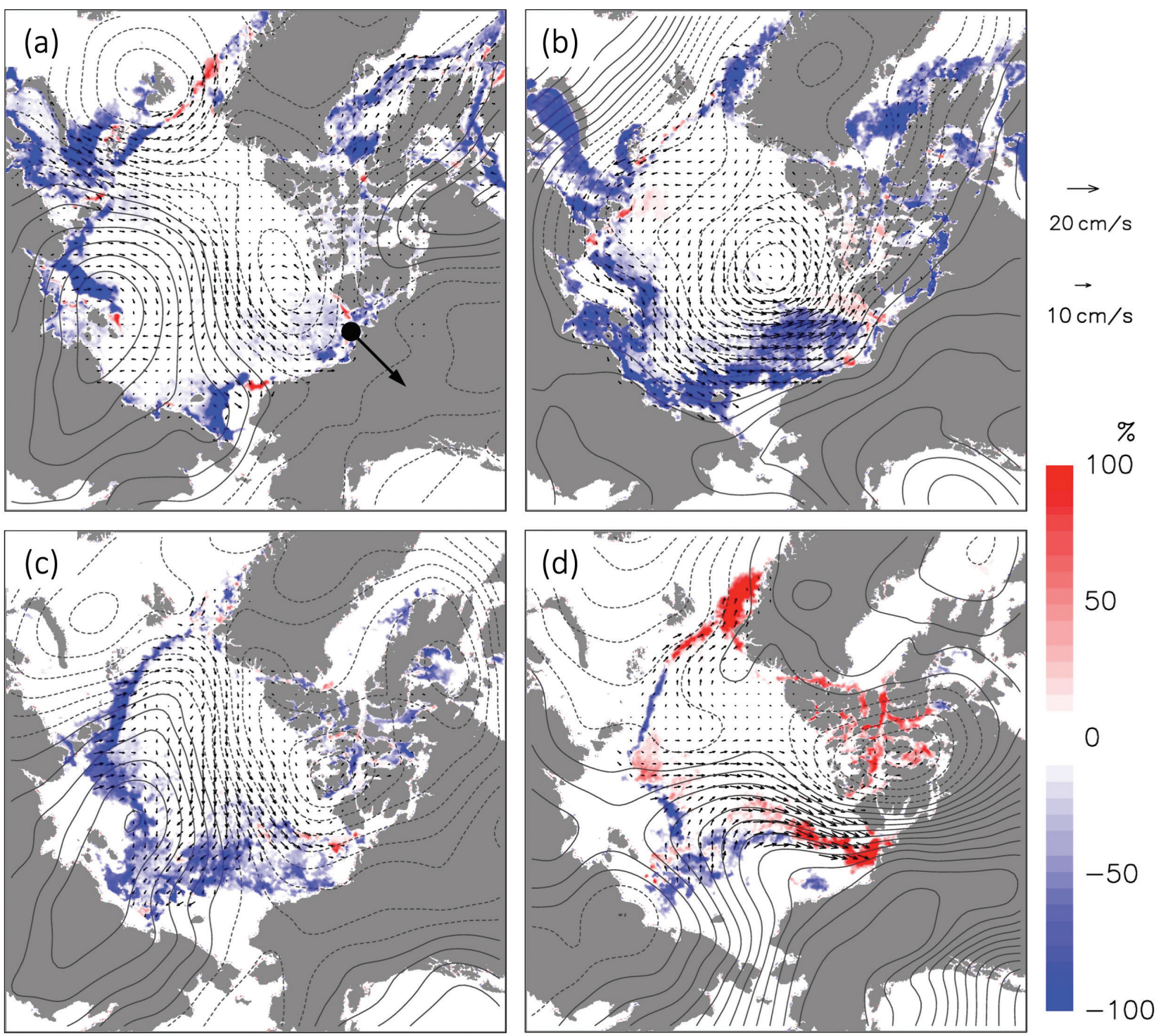

Fig. 6 Anomalies of sea-level pressure (contours) and ice velocity (vectors) in (a) June, (b) July, (c) August and (d) September 2018, based on the 2003-2018 climatology. Contour interval of the sea-level pressure anomaly is $1 \mathrm{hPa}$. A dashed contour line means a negative value. Shades of red and blue indicate differences of ice concentration between the first and last days of each month. Bold arrow in (a) is used as a reference in Fig. 7 .

a previous study reported an increase of the wind factor (Kwok et al. 2013). The wind factor of multi-year ice has increased gradually over the past few decades (Fig. 8). Linear trends of the factor for the first-year ice and multiyear ice are $0.75 \times 10^{-3}$ and $2.45 \times 10^{-3} \%$ /year, respectively. The trend of the wind factor is not significant in terms of the area of first-year ice $(99 \%$ confidence interval of the trend is $-0.13 \times 10^{-3}$ to $1.63 \times 10^{-3} \% /$ year $)$. However, the increasing trend of the factor is significant in terms of the area of multi-year ice $(99 \%$ confidence interval is $1.67 \times 10^{-3}$ to $3.23 \times 10^{-3} \% /$ year $)$.

\section{Summary}

This study demonstrates that unusual weather conditions over the Arctic Ocean are able to change the distribution of multi-year ice drastically. Blockage of the mouth of the AG by thick multi-year ice in summer 2018 occurred in two steps. First, the area of multi-year ice expanded to the North American side (Beaufort branch), where it remained from autumn 2017 to summer 2018. The appearance of the Beaufort branch overhanging towards the AG is not rare; it can be seen about once every four 


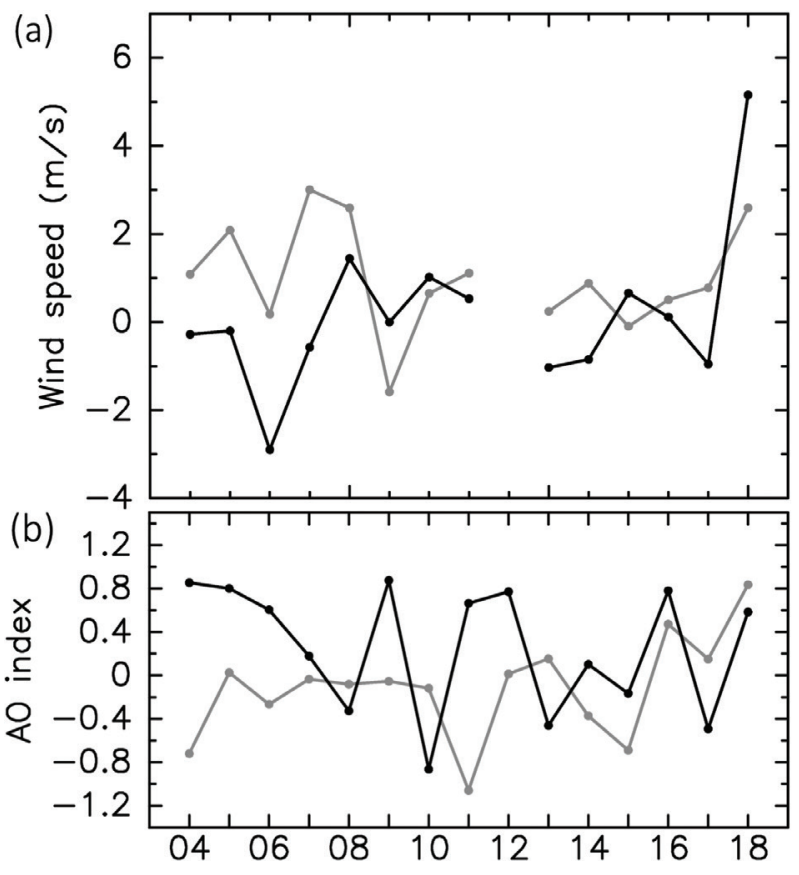

Fig. 7 (a) Inter-annual variation of monthly mean wind speed in August (grey line) and September (black line) towards right-lower direction (positive direction is shown by the bold arrow in Fig. 6a) at the centre of circle $\mathrm{B}$ (the black dot in Fig. 6a). (b) Inter-annual variation of AO index in August (grey line) and September (black line).

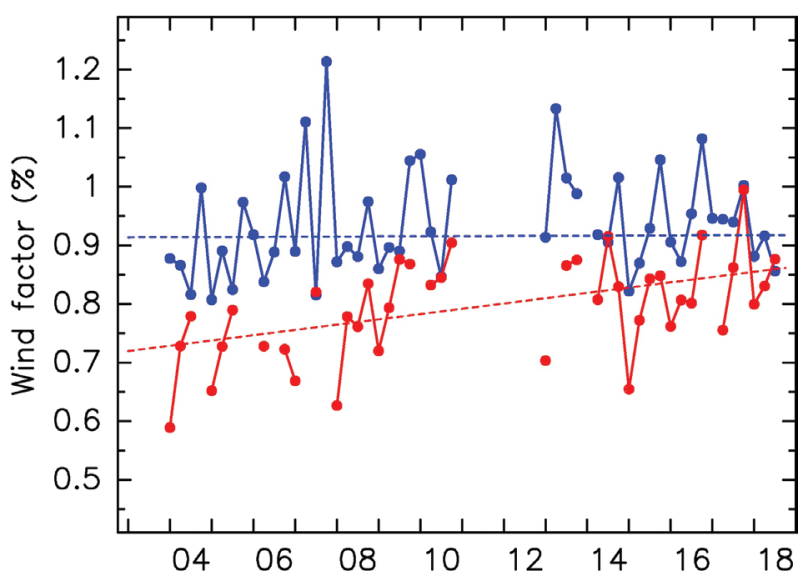

Fig. 8 Temporal changes of three-monthly (January-March, April-June, July-September and October-December) mean of the wind factor (ratio of ice drift speed to wind speed) in the entire Arctic for first-year ice (blue line) and multi-year ice (red line) during 2003-2018. Dashed lines show the linear regression lines for both first-year ice (blue) and multi-year ice (red). The area of multi-year ice is defined as the area with multi-year ice concentration $>30 \%$. years. Second, rapid migration of the Beaufort branch towards the AG was propelled by the strong AG-ward wind, especially in September 2018.

Kwok et al. (2013) reported that the wind factor has an increasing trend during both the winter and summer. Our study showed the trend is clear only in the area of multi-year ice, not in the area of first-year ice. This is probably attributable to the thinning of the multi-year sea ice. Owing to the trend, rapid movement of multiyear ice and the blockage of the sea route by thick ice have become increasingly likely year after year.

The AG is an important region of the shipping route along the North-west Passage through the Canadian Arctic Archipelago. Satellite observations can monitor the distribution of multi-year ice such as the growth of the Beaufort branch, whose timescale is from a few months to a year. Such monitoring is useful for determining the potential hazards to maritime navigation. However, rapid movement of multi-year ice and the associated blockage of sea routes can occur on short timescales (less than one month). Therefore, monthly weather forecasts will be essential for predicting such motion and helping safeguard maritime ship navigation through the Arctic Ocean shipping routes.

\section{Acknowledgements}

The authors are indebted to the Arctic Data Archive System of the National Institute of Polar Research, Japan, for the gridded AMSR-E and AMSR-2 data, and to the European Centre for Medium-Range Weather Forecasts (https://www.ecmwf.int/en/forecasts/datasets/ reanalysis-datasets/era-interim) for the ERA-Interim sealevel pressure data. The authors are grateful to the crews of the CCGS Louis S. St-Laurent and to those involved in the JOIS and Beaufort Gyre Exploration programmes. The authors thank Sarah Zimmermann for her contribution to the observations. The AO index shown in Fig. 7 is distributed by the National Weather Service of the US National Oceanic and Atmospheric Administration. Figures were produced by the GFD DENNOU Library. The authors thank James Buxton, MSc, from Edanz Group, for editing a draft of this manuscript.

\section{Disclosure statement}

The authors declare no conflicts of interest.

\section{Funding}

This work was a part of the Arctic Challenge for Sustainability (ArCS, Program Grant Number JPMXD 1300000000 ) 
and the Arctic Challenge for Sustainability II (ArCS II, Program Grant Number JPMXD 1420318865) projects.

\section{References}

Aaboe S., Breivik L.A., Sørensen A., Eastwood S. \& Lavergne T. 2017. Global sea ice edge and type product user's manual. OSI402-c $\theta$ OSI-403-c. Version 2.2. SAF/OSI/CDOP2/MET-Norway/ TEC/MA/205. Satellite Application Facility on Ocean and Sea Ice, European Organisation for the Exploitation of Meteorological Satellites. Accessed on the internet at http://osisaf.met.no/docs/osisaf_cdop3_ss2_pum_sea-iceedge-type_v2p2.pdf on 13 June 2018.

Barber D.G., Babb D.G., Ehn J.K., Chan W., Matthes L., Dalman L.A., Campbell Y., Harasyn M.L., Firoozy N., Theriault N., Lukovich J.V., Zagon T., Papakyriakou T., Capelle D.W., Forest A. \& Gariepy A. 2018. Increasing mobility of High Arctic sea ice increases marine hazards off the east coast of Newfoundland. Geophysical Research Letters 45, 2370-2379, doi: 10.1002/2017GL076587.

Cavalieri D.J. \& Parkinson C.K. 2008. Arctic sea ice variability and trends, 1979-2006. Journal of Geophysical ResearchOceans 113, C07003, doi: 10.1029/2007JC004558.

Cavalieri D.J. \& Parkinson C.L. 2012. Arctic sea ice variability and trends, 1979-2010. The Cryosphere 6, 881-889, doi: 10.5194/tc-6-881-2012.

Comiso J.C. 2009. Enhanced sea ice concentrations and ice extents from AMSR-E data. Journal of Remote Sensing of Japan 29, 199-215.

Comiso J.C. 2012. Large decadal decline of the Arctic multiyear ice cover. Journal of Climate 25, 1176-1193, doi: 10.1175/JCLI-D-11-00113.1.

Dee D.P., Uppala S.M., Simmons A.J., Berrisford P., Poli P., Kobayashi S., Andrae U., Balmaseda M.A., Balsamo G., Bauer P., Bechtold P., Beljaars A.C.M., van de Berg L., Bidlot J., Bormann N., Delsol C., Dragani R., Fuentes M., Geer A.J., Haimberger L., Healy S.B., Hersbach H., Hólm E.V., Isaksen L., Kållberg P., Köhler M., Matricardi M., McNally A.P., Monge-Sanz B.M., Morcrette J.-J., Park B.K., Peubey C., de Rosnay P., Tavolato C., Thépaut J.-N. \& Vitart F. 2011. The ERA-Interim reanalysis: configuration and performance of the data assimilation system. Quarterly Journal of the Royal Meteorological Society 137, 553-597, doi: 10.1002/qj.828.

Galley R.J., Babb D., Ogi M., Else B.G.T., Geilfus N.-X., Crabeck O., Barber D.G. \& Rysgaard S. 2016. Replacement of multiyear sea ice and changes in the open water season duration in the Beaufort Sea since 2004. Journal of Geophysical ResearchOceans 121, 1806-1823, doi: 10.1002/2015JC011583.

Haas C., Beckers J., King J., Silis A., Stroeve J., Wilkinson J., Notenboom B., Schweiger A. \& Hendricks S. 2017. Ice and snow thickness variability and change in the High Arctic Ocean observed by in situ measurements. Geophysical Research Letters 44, 10462-10469, doi: 10.1002/2017GL075434.

Hutchings J.K. \& Rigor I.G. 2012. Role of ice dynamics in anomalous ice conditions in the Beaufort Sea during 2006 and 2007. Journal of Geophysical Research-Oceans 117, C00E04, doi: 10.1029/2011JC007182.

Kimura N., Nishimura A., Tanaka Y. \& Yamaguchi H. 2013. Influence of winter sea ice motion on summer ice cover in the Arctic. Polar Research 32, article no. 20193, doi: 10.3402/ polar.v32i0.20193.

Kimura N. \& Wakatsuchi M. 2000. Relationship between sea-ice motion and geostrophic wind in the Northern Hemisphere. Geophysical Research Letters 27, 3735-3738, doi: 10.1029/2000GL011495.

Korosov A., Rampal P., Pedersen L.T., Saldo R., Ye Y., Heygster G., Lavergne T., Aaboe S. \& Girard-Ardhuin F. 2018. A new tracking algorithm for sea ice age distribution estimation. The Cryosphere 12, 2073-2085, doi: 10.5194/ tc-12-2073-2018.

Krishfield R.A., Proshutinsky A., Tateyama K., Williams W.J., Carmack E.C., McLaughlin F.A. \& Timmermans M.L. 2014. Deterioration of perennial sea ice in the Beaufort Gyre from 2003 to 2012 and its impact on the oceanic freshwater cycle. Journal of Geophysical Research-Oceans 119, 1271-1305, doi: 10.1002/2013JC008999.

Kwok R. 2018. Arctic sea ice thickness, volume, and multiyear ice coverage: losses and coupled variability (1958-2018). Environmental Research Letters 13, 105005.

Kwok R. \& Cunningham G.F. 2015. Variability of Arctic sea ice thickness and volume from CryoSat-2. Philosophical Transactions of the Royal Society A 373, article no. 20140157, doi: 10.1098/rsta.2014.0157.

Kwok R., Spreen G. \& Pang S. 2013. Arctic sea ice circulation and drift speed: decadal trends and ocean currents. Journal of Geophysical Research-Oceans 118, 2408-2425, doi: 10.1002/jgrc.20191.

Mahoney A.R., Hutchings J.K., Eicken H. \& Haas C. 2019. Changes in the thickness and circulation of multiyear ice in the Beaufort Gyre determined from pseudo-Lagrangian methods from 2003-2015. Journal of Geophysical ResearchOceans 124, 5618-5633, doi: 10.1029/2018JC014911.

Maslanik J.A., Fowler C., Stroeve J., Drobot S., Zwally J., Yi D. \& Emery W. 2007. A younger, thinner Arctic ice cover: increased potential for rapid, extensive sea-ice loss. Geophysical Research Letters 34, L24501, doi: 10.1029/ 2007 GL032043.

Maslanik J.A., Stroeve J., Fowler C. \& Emery W. 2011. Distribution and trends in Arctic sea ice age through spring 2011. Geophysical Research Letters 38, L13502, doi: 10.1029/2011GL047735.

Ricker R., Hendricks S., Helm V., Skourup H. \& Davidson M. 2014. Sensitivity of CryoSat-2 Arctic sea-ice freeboard and thickness on radar-waveform interpretation. The Cryosphere 8, 1607-1622, doi: 10.5194/tc-8-1607-2014.

Stroeve J., Holland M.M., Meier W., Scambos T. \& Serreze M. 2007. Arctic sea ice decline: faster than forecast. Geophysical Research Letters 34, L09501, doi: 10.1029/2007GL029703.

Thorndike A.S. \& Colony R. 1982. Sea ice motion in response to geostrophic winds. Journal of Geophysical ResearchOceans 87, 5845-5852, doi: 10.1029/JC087iC08p05845.

Tilling R.L., Ridout A. \& Shepherd A. 2018. Estimating Arctic sea ice thickness and volume using CryoSat-2 radar 
altimeter data. Advances in Space Research 62, 1203-1225, doi: 10.1016/j.asr.2017.10.051.

Tschudi M.A., Stroeve J.C. \& Stewart J.S. 2016. Relating the age of Arctic sea ice to its thickness, as measured during NASA's ICESat and Ice Bridge campaigns. Remote Sensing 8 , article no. 457, doi: 10.3390/rs8060457.

Weber B. 2018. Arctic communities won't get crucial supplies after barge cancelled due to excess sea ice. The Canadian
Press, 3 October. Accessed on the internet at https://globalnews.ca/news/4513776/arctic-barge-cancelled-supplies/ on 7 September 2020.

Worby A.P. \& Allison I. 1999. A technique for making ship-based observations of Antarctic sea ice thickness and characteristics. Part I: observational technique and results. Antarctic Cooperative Research Centre Research Report $14,1-23$. 